This item was submitted to Loughborough's Research Repository by the author.

Items in Figshare are protected by copyright, with all rights reserved, unless otherwise indicated.

\title{
Limiting role of resource dependence: an examination of director interlocks, board meetings and family ownership
}

PLEASE CITE THE PUBLISHED VERSION

https://doi.org/10.1108/CCSM-01-2020-0006

PUBLISHER

Emerald Publishing Limited

VERSION

AM (Accepted Manuscript)

PUBLISHER STATEMENT

This paper was accepted for publication in the journal Cross Cultural \& Strategic Management and the definitive published version is available at https://doi.org/10.1108/CCSM-01-2020-0006.

LICENCE

CC BY-NC 4.0

\section{REPOSITORY RECORD}

Sukumara-Panicker, Vidya, and Rajesh Srinivas Upadhyayula. 2020. "Limiting Role of Resource Dependence: An Examination of Director Interlocks, Board Meetings and Family Ownership”. Loughborough University. https://hdl.handle.net/2134/13109876.v1. 


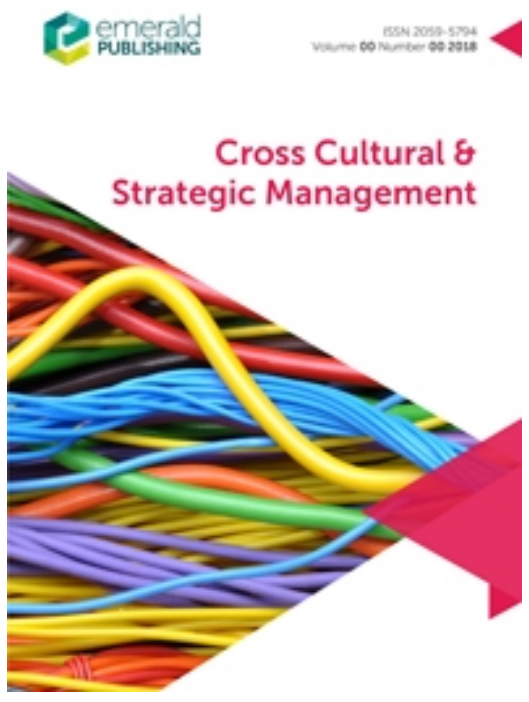

Limiting Role of Resource Dependence: An examination of director interlocks, board meetings and family ownership

\begin{tabular}{|r|l|}
\hline Journal: & Cross Cultural \& Strategic Management \\
\hline Manuscript ID & CCSM-01-2020-0006.R1 \\
\hline Manuscript Type: & Research Paper \\
\hline Keywords: & $\begin{array}{l}\text { Boards of Directors, Emerging Market, Corporate Goverance, Family } \\
\text { firms, Internationalisation }\end{array}$ \\
\hline \multicolumn{2}{|l}{} \\
\hline
\end{tabular}

\section{SCHOLARONE ${ }^{\mathrm{m}}$ \\ Manuscripts}




\title{
Limiting Role of Resource Dependence: An examination of director interlocks, board meetings and family ownership
}

\begin{abstract}
- Purpose - This paper attempts to examine the activity and involvement of board of directors in internationalization activities of firms in emerging markets, by evaluating the resource provisioning roles of interlocks provided by board of directors, and the frequency of board meetings. We demonstrate that the effectiveness of board involvement is contingent upon the levels of family ownership in firms since family ownership could impact the firm's ability to utilize the presence of different types of board members.
\end{abstract}

- Design/methodology/approach - We test our hypotheses on a sample of listed Indian companies, extracted from the Prowess database published by the Centre for Monitoring Indian Economy (CMIE), a database of the financial performance of Indian companies. On a panel of 3133 firm years of 605 unique Indian firms with foreign investments, over a time period of 2006-2017, we apply different estimation techniques.

- Findings - The results demonstrate that both board meeting frequency as well as director interlocks are instrumental in supporting internationalization activities in emerging market firms. However, family ownership moderates the role of insider and independent interlocks on internationalization investments in different ways; we find that interlocks provided by independent directors support internationalization activities in family firms, whereas interlocks provided by insider directors do not. Further, the study also finds that board meetings are less effective in internationalization of family firms.

- Practical implications - We conclude that family firms aiming at international diversification require to develop more connected and networked independent directors to enable internationalization in firms. While independent director interlocks enhance the international investments, it is also useful to know that board meetings are ineffective in utilizing the resources in family firms. This points to the possibility that family firms should device mechanisms to integrate family meetings with board meetings so that they can utilize the within-family processes to aid in their internationalization decisions. 
- Originality/value - We contribute to resource dependence theory by understanding its limiting role in family firms. Theoretically, we help delineate the limiting resource provision role of the insider directors vis-à-vis independent directors. We argue that the resource provision role of insider director interlocks does not effectively help in internationalization in comparison to independent director interlocks in family dominated firms. Consequently, our study shows the limiting role of resource provision and utilization by family owned firms in comparison to non-family owned firms.

- Keywords- Board involvement, Board meetings, Director interlocks, Emerging markets, Family ownership, Independent directors, Insider directors, Internationalization

- Paper type - Research paper

\section{Introduction}

Internationalization as a firm growth and survival strategy has never been more important; the disappearing world boundaries demand and encourage international presence of firms (Barroso et al., 2011). Emerging market firms are not exceptions to this (Gaur and Kumar; 2009), and increasing liberalization and a reduction in trade barriers have made it easier as well as necessary for many firms to expand into foreign markets (Khanna, Kogan and Palepu, 2006). A major trigger of internationalization activities in firms is their board of directors (Boeker and Goodstein, 1991; Goodstein et al., 1994; Grinyer and McKiernan, 1990; Mizruchi and Stearns, 1988; Pearce and Zahra, 1992; Pfeffer, 1972; Sherman et al, 1998). Consequently, research in the context of emerging markets (e.g. Chen, 2011; Singh and Delios, 2017) have attempted to establish the relationship between the characteristics of board and international investments, from a resource dependence perspective. Further, evidence from emerging markets often demonstrates the ineffectiveness of board mechanisms and the contingencies associated with board characteristics such as board independence and CEO duality in influencing internationalization decisions (Singh and Delios, 2017; Singla, Veliyath and George, 2014). These inconsistent empirical outcomes have resulted in two further developments in extant literature. Firstly, to gain a greater understanding on resource access or utilization, studies on governance and strategic management in firms are increasingly considering involvement of board of directors, such as director interlocks and board meeting frequency, rather than only board constitution (e.g. Sarkar, Sarkar and Sen, 2008; Shu et al., 2015; Singh and Delios, 2017). Secondly, additional contingencies such as ownership structure could also influence board 
characteristics, thus necessitating their inclusion in examining relationship between board of directors and internationalization (e.g. Ramón-Llorens, García-Meca and Duréndez, 2017; Sciascia et al., 2013).

We incorporate both these lines of enquiry in our study, from a resource dependence view, which asserts that the board is an integral component of the effective firm, and helps firm gain access to scarce resources and information (Boyd, 1990; Pennings, 1980; Pfeffer and Salancik, 2003). Firstly, we consider two specific aspects of board involvement, viz., director interlocks and frequency of board meetings on internationalization investments in emerging market firms. These two characteristics of the board are often considered to be representative of the involvement and activity of the board of directors in the corporate governance of a firm (e.g. Jackling and Johl, 2009; Lipton and Lorsch, 1992). Theoretically, it is established that linkages to the environment through director interlocks improves the resource advantages that a firm possess, and hence can influence the strategic decisions and performance outcomes in firms (e.g. Jackling and Johl, 2009; Singh and Delios, 2017; Zona, Gomez-Mejia and Withers, 2018). Further, frequency of board meetings has also been identified as an important dimension of board operations (Carter et al. 2003; Vafeas, 1999; Xie et al. 2003) and hence, can have consequences on the effectiveness and resource acquisition ability of firms (Jackling and Johl, 2009; Johl, Kaur and Cooper, 2015). At the same time, in the context of emerging economies the importance of institutional environment and family ownership in determining their governance arrangements is often highlighted (Aguilera, Filatotchev, Gospel, and Jackson, 2008; Coles, Daniel, and Naveen, 2008). For instance, in emerging markets, it is not uncommon to find boards which are dominated by insider directors, who have very close connection with ownership groups such as families (Khanna and Palepu, 2000a). In such contexts, we argue that family ownership, in conjunction with board director interlocks as well as board meetings affects decision making differently in comparison to non-family firms.

We enhance resource dependence theory by exploring the relationship between the type of board involvement and international investments in emerging market firms. It has been identified that the prominent role of board of directors in emerging market firms is in providing critical resources in the form of human and social capital to owners and managers of the firm rather than disciplining/monitoring role in developed markets (Chen, 2011; Chen and Hsu, 2009; Choi, Park and Yoo, 2007). This ability of the board of directors, where they can bring resources to the board encompasses their resource provisioning role (Garg and Eisenhardt, 
2017; Hillman, Withers and Collins, 2009). In this paper, we argue that higher levels of board involvement, in the form of interlocks and meetings, can ensure higher levels of resource provisioning, thereby supporting internationalization activity in firms. We provide two further extensions to the understanding of this relation. Firstly, we differentiate between the interlocks provided by independent and insider directors in family firms. While it has already been established that the resource advantages offered by independent directors are different to that of insiders (Baysinger and Hoskisson, 1990; Judge and Zeithaml, 1992), we argue that the interlocks and resources provided by these interlocks therein differ between firms having higher family ownership and lower family ownership (Ferris, Jagannathan and Pritchard, 2003; Singh and Delios, 2017). Secondly, in emerging markets with high levels of ownership concentration, there isn't sufficient separation between ownership and board, various ties exist between family has strong ties with other stakeholders of the firms, such as board of directors (Silva, Majiluf and Paredes, 2006). Essentially, this implies that the effect of board activity on internationalization activities of emerging market firms is contingent upon the level of family ownership. Combining these premises, in our paper, we aim to understand how interlocking ties of different types of board of directors and board meeting frequency influence international investments in emerging markets firms as well as how family ownership moderates this relationship.

Our sample consists of 3133 data points of 605 unique Indian firms with foreign investments, in a time period of 2006-2017. On this sample, we apply different panel regression estimation techniques, including random effects GLS regression and Heckman 2-stage estimation. Our results show that both insider and independent director interlocks have a positive relationship with international investments of emerging market firms. Further, our results also highlight the positive relationship between board meeting and international investments in firms. Additionally, we find that insider interlocks are less effective in supporting internationalization activities in family owned firms, whereas independent interlocks are more effective in family owned firms and their internationalization activities. Finally, we find that board meetings are less effective in promoting internationalization in firms with high family ownership, possibly due to the importance that family meetings have in such firms, which diminish the role of formal board meetings.

This study contributes to the extant literature and practice in the following ways. Firstly, consistent with studies in emerging markets, we find that resource provisioning role of director 


\section{Theory and literature review}

Johnson, Daily and Ellstrand (1996) summarize that the board of directors traditionally fulfil three roles; control, service/collaboration and provision of resources. Different theoretical perspectives have been applied to understand how each of these impact firm performance and strategies. While agency theory is the primary point of view in understanding monitoring and control role of board of directors in firms (e.g. Langevoort, 2001; Sundaramurthy and Lewis, 2003), resource dependency perspective also has received a high level of attention, where the directors are considered to be a source of resource, networks and information (Carpenter and Westphal, 2001;Goodstein, Gautam, and Boeker, 1994; Hillman, Cannella and Paetzold, 2000; Korac-Kakabadse et al., 2001; Pfeffer and Salancik, 2003). Another set of studies also attempt to integrate the two roles (Hillman and Dalziel, 2003; Dalziel, Gentry, and Bowerman, 2011; Zona, Gomez-Mejia, and Withers, 2018).

However, we argue that the most predominant role of board of directors in emerging markets is the resource provisioning role (e.g. Singh and Delios, 2017). Resource provisioning addresses the ability of the board to bring resources to the firm, where resources are "anything that could be thought of as a strength or weakness of a given firm" (Wernerfelt 1984, p. 172). 
Firms from emerging markets could face resource scarcity as capital markets, labor markets and products markets in these countries are relatively less developed (Chacar and Vissa, 2005; Elango and Pattnaik, 2007; Khanna and Palepu, 2000b), and hence, they need more linkages with the external environment (Boyd, 1990), making the resource provision role of the board more important. In their resource provisioning role, board of directors can offer legitimacy, reputational advantages and enhanced public image to the firm (Bazerman and Schoorman, 1983), provide expertise, counsel and advice (Baysinger and Hoskisson, 1990, Carpenter and Westphal, 2001, Westphal, 1999), facilitate access to resources such as capital (Mizruchi and Stearns, 1994), support and aid the formulation of strategy or other important firm decisions (Judge and Zeithaml 1992, Lorsch and MacIver 1989).

Studies on emerging markets also posit that board of directors is the link between firm and its environment, which helps the firm secure critical resources (Saeed, Yousuf and Alharbi, 2017). Extant literature has examined board interlocks from the resource dependence perspective. (Carpenter and Westphal, 2001; Westphal, 1999). In this view, the interlocked directors on the board are found to have more effective information processing skills due to their experience from similar roles (Dearborn and Simon, 1958; Walsh, 1995) and this exposure also guarantee them a greater understanding about business practices and policies (Palmer, Jennings, and Zhou, 1993).

The resource provisioning role of board of directors becomes even more significant in the context of internationalization of emerging market firms. This is because these firms are generally less resource endowed and less competitive compared to firms from developed economies (Aulakh et al., 2000), potentially impairing their ability to internationalization. However, board of directors can bring in international experience and industry specific experience to the firm, thereby enabling the firm to develop a knowledge of opportunities for expansion into new international markets and also in managing relationships and operations in the new environment (Hitt et al. 2006; Barroso et al. 2011; Chen et al., 2017). Board of directors can also facilitate access to critical information and value resources, that could aid the internationalization process in emerging market firms (Kor and Sundaramurthy 2009; Ortizde-Mandojana et al. 2012). We further examine how board interlocks and frequency of board meetings support internationalization in firms.

2.1. Director interlocks and firm internationalization 
The literature on the effectiveness of interlocked boards is equivocal and some address it as a 'double-edged sword' (Jackling and Johl, 2009). On the flip side, multiple board appointments are found to compromise the ability of directors to commit themselves to any particular firm due to their over-commitment in multiple firms (Core, Holthausen and Larcker, 1999; Fich and Shivdasani, 2007; Shivdasani and Yermack, 1999). Arguments on the other side of the debate shows that that directors with multiple board appointments, however, can utilize and derive advantages out of the many networks they have, by accessing resources, suppliers and customers to a firm (Booth and Deli, 1996; Mizruchi and Stearns, 1994; Pfeffer, 1972). They therefore act as resource providers, who offer network linkages to the firm. Examining these two perspectives theoretically, while agency scholars contend that board interlocks reduce performance by fostering managerial opportunism (Fich, 2005; Perry and Peyer, 2005; Rosenstein and Wyatt, 1994), resource dependence scholars maintain that interlocks improve performance by relaxing resource constraints (Mizruchi, 1996; Pfeffer, 1987).

From the resource provisioning role that we envision the board of directors to offer to firms in emerging markets, we therefore further examine the benefits of board interlocks in the internationalization of firms. Firstly, interlock directorates offered by directors can assist a firm in negotiating uncertainties and challenges associated with international investments. Internationalization, while fast becoming a necessary and valuable strategy for firms (Graves and Thomas, 2008), is also accompanied by considerable risk, complexity, and uncertain outcomes, and is one of the most important challenges firms face (Datta, Musteen and Herrmann, 2009). Additionally, termed as 'liability of foreignness' (Hymer, 1976), emerging markets firms also face challenges in terms of their knowledge of foreign cultures and markets (Caves, 1971; Kostova and Zaheer, 1999). In this context, interlocked boards support internationalization by facilitating transfer of critical culture and market knowledge among the firms that they are associated with. From a socio-cognitive perspective, this transfer happens since the information-processing among individuals are found to be developed from their experience in similar roles (Dearborn and Simon, 1958; Walsh, 1995). Involvement of directors in multiple boards are an important source of information about business practices and policies (Mizruchi, 1996; Palmer, Jennings, and Zhou, 1993) and is found to be useful in scanning the environment for timely and pertinent information (Useem, 1982). 
Secondly, an interlocked board also helps in opportunity recognition for emerging market firms in the international market. Research establishes that in order to identify and explore new opportunities in international markets, a wide base of resources is required. This is facilitated not only by the capabilities and experience of the management board, but also through their contacts and networks (Mitter et al., 2014; Westhead et al., 2001). A more interlocked board hence provides greater connections and networks for opportunity recognition in emerging market firms. Overall, firm with greater linkages through board interlocks are found to be more capable of identifying and pursuing growth opportunities in firm by establishing linkages with external environment, by placing firms favourably in external environment and by helping firm access resources more effectively (Gulati, 1998; Singh and Delios, 2017; Zona et al., 2018).

At the same time, literature discusses the need to separate independent and non-independent (insider) directors while considering director interlocks (e.g. Ferris, Jagannathan and Pritchard, 2003) and hence, we separately examine the implications of interlocks among insider and independent directors, on firm internationalization.

It has been found that the linkages with external environment offered by external and independent board members are a source of competitive advantage for firms in emerging markets (Gaur and Kumar, 2009; Singh and Delios, 2017), and these linkages offer them resources for growth and survival (Pfeffer and Salancik, 2003). Independent directors, through their interlocking directorates, provide a firm's executives with information and alternatives that are being pursued or considered by related firms and industries, which could benefit the internationalization strategies of the focal firm (Sherman, Kashlak and Joshi, 1998). More specifically, Luo (2007) suggests that independent directors who possess strong network ties can mitigate the liability of foreignness for emerging market firms entering a foreign market. Firms that have a high interlock of professional independent directors are also found to assist the firms in being aware of the potential benefits from internationalization, and also help firms to respond effectively on complex strategic choices such as internationalization (Purkayastha, Manolova and Edelman, 2016). Thus, interlocking directorate ties enable independent directors to provide access to critical resources essential for entering foreign markets (Chen, Hsu and Chang, 2016). Therefore, we hypothesize, 
H1: Director interlocking among independent directors in boards is positively related to the level of internationalization in emerging market firms.

Despite being criticized in their role as monitors of the management, insider directors are acknowledged as efficient resource providers to a firm, since they are better informed regarding firm projects and can contribute valuable insights, advice, and information to board discussions (Baysinger and Hoskisson, 1990; Judge and Zeithaml, 1992). Firms in emerging markets are also willing to supply their insider directors (including CEOs) as outside directors to other firms, to bond their relationship with other firms in their supply chain (Booth and Deli,1996). Further, insiders and executives as board members in other firms also helps them to learn about alternative management styles and strategies that can benefit the sending firm (Fahlenbrach, Low and Stulz, 2010; Perry and Peyer, 2005). Inside directors in emerging markets are found to carry important weight across the group's directorate structure because of their reciprocal ownership relations across companies (Pombo and Gutiérrez, 2011; Westphal and Zajac, 1997). This implies that insider interlocks constitute a network of relations among firms, where insider directors from individual firms take their place as directors in other firms through a reciprocal arrangement. Such interlocks help reconstitution of broken or disrupted interlock ties between firms (Palmer, 2002) and helps reduce information uncertainties created by resource dependencies between them (Pettigrew, 1992). Insider directors with intimate company and industry knowledge are more effective and involved in strategic decision-making process (Baysinger and Hoskisson, 1990; Johnson, Hoskisson, and Hitt, 1993; Judge and Zeithaml, 1992; Ruigrok et al., 2006) and hence the interlocks they provide with other firms would enhance the chances of international investments in firms. Singh and Delios (2017) argue that the network ties provided by insider directors can in fact be even stronger than that of independent directors. This is because insiders of a firm are particularly interested in growth opportunities such as internationalization, since that will boost their career growth. This leads them to scanning the external environment more effectively for growth opportunities of the firm and using their interlocks to extract information and derive other advantages from the network (Singh and Delios, 2017). Further, because they understand the strengths and weaknesses of their firm better (Donaldson and Davis, 1991; Donaldson, 1995), they are more effective in using their interlocks to identify internationalization opportunities that are best suited to the resource configuration of their firm (Singh and Delios, 2017).

Therefore, we hypothesize 
H2: Director interlocking among insider directors in boards is positively related to the level of internationalization in emerging market firms.

Board meeting and firm internationalization

Board meeting frequency represent the level of directors' involvement in the firm (Brick and Chidambaran 2010; Ntim and Osei 2011). Therefore, board meeting frequency is increasingly being used as a proxy for active boards, board diligence and board effectiveness (Carcello et al. 2002; Carter et al. 2003; Conger et al. 1998; Min and Chizema, 2018; Xie et al. 2003). As in the case of board interlocks, the relation between board meeting frequency and firm performance has also been subject to scrutiny, with results supporting both sides of the argument. One side of the debate argues that board meeting is a routine process which might absorb much of a director's time, without any meaningful involvement from outsider members, and also that higher board activity symbolizes a response to poor performance (Jensen, 1993). However, from the resource dependence theoretical perspective, literature presents ample evidence to support the importance of board meetings in internationalization of firms. Firstly, board and committee meetings are pivotal in informing and involving directors in the decisionmaking process in firms (Tuggle et al., 2010), and hence, board meetings forums are important for a firm involved in internationalization activities (Martini, Corvino and Rigolini, 2012). Frequent board meeting are required to help members gain a better understanding of the internationalization activities of the firm, facilitate the evaluation of new, potential projects and provide more opportunities for board members to confer, to set strategy and to manage the operational complexity of the strategic decisions facing the firm (Wincent, Anokhin and Ortqvist; 2010). Secondly, there are linkages between frequency of board meetings and the effectiveness of a board performing strategic roles (Demb and Neubauer 1992; Huse 1995). Frequency of board meetings gives the members opportunities to agree on strategy, react to problems, and deal effectively with complex situations and environments (Huse, 2000; Zahra, 1990) such as the ones involved in internationalization decision of firms. Further, board meetings also enable the members of the board to build networks and relationships among themselves. Interlocked directorates provided by directors are also found to be most effective in facilitating resource acquisition when there are frequent board meetings (Chen and Hsu, 2009; Chen, 2012; Gabrielsson and Winlund, 2000). Overall, board meetings are the primary mechanism for board of directors to keep informed of a firm's operations (Masulis et al., 2012), business conditions and managerial decision making (Adams and Ferreira, 2008), so that they 
can effectively participate in a firm's governance (Lipton and Lorsch, 1992) and review and assist in major strategic actions (Haynes and Hillman, 2010). Additionally, board meetings also help handle complexities, develop strategic alternatives and reduce uncertainties, consequently leading to a greater likelihood of successful firm activities (Chen, 2012), thereby increasing the willingness of the firm to invest in internationalization.

Empirically, in the context of Sweden, the relation between formalized meetings (both at firm and TMT levels) have been found to influence international activities of firms (Andersson, Gabrielsson and Wictor, 2004). It should also be noted that in the emerging markets context, board meetings are deemed necessary to ensure sufficient interaction between insiders and outsiders, so that the outsiders remain well informed of the strategic intent of the firm (Martini et al., 2012). Therefore, we hypothesize the following:

H3: Frequency of board meetings in a firm is positively related to its level of internationalization

2.2. Family ownership as moderator in board activity - internationalization relation

Many studies discuss the contingencies involved in the relationship between different governance mechanism and firm strategies (e.g. Chen and Hsu, 2009; Singh and Delios, 2017). For instance, the governance characteristics of a firm can interact among themselves, affecting firm level strategies. In this regard, while the tendency and ability of family ownership to alter board behaviour from a monitoring perspective have been well understood (e.g. Anderson and Reeb, 2004; Barontini and Caprio, 2006; Brunello et al., 2003; Silva and Majluf, 2008), the impact of family ownership on board advisory role is not as well-researched. Therefore, we attempt to answer the call to understand the ability of boards to provide advisory roles in different contexts (such as family owned firms), and to develop a more nuanced understanding of the board-strategy relationship (Bammens, Voordeckers and van Gils, 2011).

Family ownership in emerging markets is found to influence internationalization negatively, owing to reasons such as fear of loss of control and high risk-perception (Bhaumik, Driffield and Pal, 2010; Panicker et al., 2019, Ray, Mondal and Ramachandran, 2018). Since familydominated boards potentially grant a disproportionate voice to the family in the firm's decision making (Anderson and Reeb, 2004), the effectiveness of board activities could also vary according to the levels of family ownership in the firms. This is because, as a concentrated shareholder with majority ownership in the firms, families can dominate the board of directors of these firms (Dharwadkar et al., 2000; Young et al., 2008; Varma, 1998). The board of 
directors of such firms are often constituted based on kinship, social and family ties, resulting in the presence of non-independent, insider directors, affiliated to the family (Kang and Shivdasani, 1995; Khanna and Rivkin, 2001). Interlocking directorates in family firms are unique in the sense that family firms often use interlocks to build their social capital (Lester and Cannella, 2006), where social capital refers to the mechanisms through which family owners protect and nurture their family businesses (Bourdieu, 1986; Putnam, 1993). From a resource dependence perspective, interlocks among family firms provide resources to the firms involved, helping each other to navigate uncertainty in the environment (Kono, Palmer, Friedland, and Zafonte, 1998). Moreover, family owned firms are found to have a higher propensity to form director interlocks with other family owned firms and within the ethnic community (Cannella, Jones and Withers, 2015). We further examine the impact of family ownership on the interlocks provided by independent and insider directors separately.

We argue that family firms can derive significant benefits out of independent directors and the network interlocks that they can offer. Firstly, it has been identified that boards of familycontrolled firms often consist of a majority of family members, close friends, as well as business associates (Young et al., 2001). Such firms therefore require more external linkages, networks and resources through alternative means and mechanisms such as independent directors with network linkages, outside resources and contacts (Sharif, Kyid and Wei, 2015). Further, in emerging markets, external environment plays an important role in capability building in firms (Gaur and Kumar, 2009) and therefore, relational capital through external connections become extremely important in the growth strategies of these firms (Khanna and Palepu, 2000b). Indian business groups, in particular, have been found to rely on relational capital provided by independent directors, in their growth strategies such as internationalization (Singh and Delios, 2017). Owing to the above, family firms draw distinct resources from the independent director interlocks in comparison to insider director interlocks. Therefore, we anticipate that family firms would derive greater benefits out of independent director interlocks. Consequently, we hypothesize,

H4: Family ownership positively moderates the relation between independent board interlocks and internationalization

Risk aversion of family owners towards internationalization strategies in emerging markets is established in literature (Bhaumik, Driffiled and Pal, 2010; Panicker, Upadhyayula and Mitra, 
2019; Ray, Mondal and Ramachandran, 2018). It is plausible that if the owners of a firm do not want to pursue a particular strategy, as their representatives, the network linkages and contributions of insider directors towards that strategy is not very significant (Luan and Tang, 2007). Additionally, in comparison to non-family firms, family firms are found to prefer hiring insiders from their closely-knit networks and this disposition could limit their access to new external resources (Sharif, Kyid and Wei, 2015). In case of emerging markets, for family owned firms and firms that belong to conglomerates such as business groups, there exist dense networks of all kinds of intercorporate ties among firms belonging to same ethnic groups (Granovetter, 1995) or affiliated firms (Khanna and Palepu, 2000b; Kali, 1999). The ties offered by insider directors in such firms can mostly capitalize on opportunities within the domestic environment, therefore, are unable to provide additional external resources for internationalization activities. Hence,

\section{H5: Family ownership negatively moderates the relation between insider board interlocks and internationalization}

In family owned firms, it is found that family institutions such as informal get togethers, formal family meetings, family councils, and family plans are pivotal in protecting the interests of owner-family members (Mustakallio, Autio and Zahra, 2002). Hence such meetings hold an important place in the decision-making process as well within these firms, with strategic implications (Habbershon and Astrachan, 1997) and are sometimes more significantly used than written business plans or board meetings (Astrachan and Kolenko, 1994). Some studies have also observed a substitution of board meetings with family meetings, wherein family firms might sometimes replace board meetings with regular family meetings (Brunninge and Nordqvist, 2004; Gersick et al., 1997; Neubauer and Lank, 1998). There are also cases where family meetings are organized before each board meeting to agree on the board agenda (Ward and Handy, 1988). Further, in family owned firms, the directors themselves are also found to provide counsel to family members in informal settings outside the board meetings (Mustakallio, Autio and Zahra, 2002; Wennberg et al., 2011), further lowering the importance of formal board meetings. Hence, the board meetings may not contribute significantly in evaluating internationalization opportunities for family firms. Consequently, the effectiveness of board meetings is lower in family owned firms, where family meetings and informal interactions between family and the board members could often substitute for formal board meetings. Therefore, we hypothesize the following: 
H6: Family ownership negatively moderates the relation between board meetings and internationalization

\section{Data and methodology}

We test our hypotheses on a sample of listed Indian companies, extracted from the Prowess database published by the Centre for Monitoring Indian Economy (CMIE), a database of the financial performance of Indian companies. India's economy is classified as emergent or developing (Jain, 2006; Chakrabarti, Megginson and Yadav, 2007), and this offers us a contrast again United States and European countries where majority of the research in this area have been focused. The original dataset was to be made up of all listed companies in the Prowess database for the period of 2006 to 2017. 2006 is chosen as the starting point for two reasons. Firstly, most of the major changes to the Clause 49 (clause providing guidelines on Corporate Governance) of the listing agreement to the Indian stock exchange were implemented in stages between 2000 and 2005, making 2006 an ideal point of starting our analysis. Secondly, there is a greater level of disclosure and consistency in data availability of Indian firms from mid-2000, in comparison to other previous years (Abraham, Marston, and Jones, 2015). We extracted the initial sample of all listed firms and removed sample firms with missing data that could not be retrieved through any databases or sources. Our sample has firms representing 6 primary industries as per the National Industry Classification (NIC): Manufacturing, services, construction, mining, agriculture, transportation. Firms belonging to finance, insurance, and real estate were dropped from the final sample since these firms are governed by a different set of corporate governance regulations (Faccio and Lasfer, 2000; Jaiswall and Banerjee, 2012). The final sample for the study consisted of 3133 firm years, of 605 unique firms.

\subsection{Dependent variable}

Consistent with the extant literature, we use the log of annual foreign investments to measure internationalization, as is frequently found in emerging market studies (Gaur, Kumar, and Singh, 2014; Singh and Delios, 2017; Singh and Gaur, 2013; Panicker et al., 2019). The decision of a firm to invest in cross-border production is among the most visible and important aspects of internationalization (Dunning, 1998) and hence FDI investments is often considered the most important criterion for the internationalization of firms (Hasselet al., 2003).

\subsection{Explanatory variables}


Our explanatory variables are board meeting frequency and director interlocking among independent and insider directors. Board meeting frequency is the total annual board meetings held by the firm (Jackling and Johl; 2009). The classification of independent directors and insider directors are based on the reported director types in the CMIE Prowess database. From the superset of directors, we first remove nominee and other institutional representatives. The director interlocks are measured as the proportion of total interlocks provided by the directors to the total number of directors (Filatotchev, 2006; Ortiz-de-Mandojana et al., 2012), for each firm-year. We have two different variables for interlock, independent director interlock and insider director interlock. Table 1 further explains the computation of each of these variables.

\subsection{Control variables}

Family ownership is measured in terms of the proportion (\%) of equity held by family owners. Following Ashwin, Krishnan and George (2015), we include shares held by individual family owners as well as corporate promoters, since family owners along with their direct ownership also control firms through intercompany crossholding and holding companies. Board composition is measured by board independence (ratio of independent board members to the total board size), board size and CEO duality (Singh and Gaur, 2013; Singh and Delios, 2017). We employ a dummy variable to indicate whether the firm is business group affiliated or not and also control for institutional shareholdings. Extant literature has identified other variables that affect the level of internationalization of a firm. These include size of the firm (Log of total assets), profitability of the firm (Return on assets), R\&D intensity, Debt to Equity ratio of a firm, age of the firm and the industry to which the firm belongs (e.g. Tihanyi et al., 2003; Gaur and Kumar, 2009; Autio, Sapienza and Almeida, 2000; Singh and Gaur, 2013; Singh and Delios, 2017). These variables are also controlled for in our study.

\section{Insert table 1 about here}

\subsection{Analytical procedure}

We estimate the relation between board characteristics and internationalization in our sample firms using GLS panel regression estimation techniques. We choose random effects estimation over fixed effects estimation since the Hausman test on our sample showed that random effects estimation is more appropriate. Also, the presence of time invariant variables, 
such as family ownership, business group affiliation, and specific industry effects support a random effects estimation. Further, we have considered a one-year lag between the dependent variable and the explanatory variables. Therefore, international investments at time $\mathrm{t}$ will be determined based on the conditions existing in time $\mathrm{t}-1$.

\section{Results}

The descriptive statistics and correlation matrix are provided in Table 2. We find that there is significant collinearity between certain variables. Therefore, we ran regressions to test Variance Inflation Factors (VIF) for all the models. We found that all the variables had a VIF score of less than 5, eliminating any potential threat of significant multi-collinearity in our analyses.

Insert table 2 about here

We perform hierarchical regressions on our sample. In model 1, we analyse the direct association between both kinds of director interlocks, board meetings and international investments. In models 2, 3 and 4, we include the interaction effects of family on the interlocks and board meetings. Model 5 includes all direct and interaction effects.

The results of GLS random effects analyses are presented in table 3. From table 3, model 1, we find that independent director interlocks, insider director interlocks and board meeting frequency are positively related to international investments in our sample firms. Therefore, we find support for $\mathrm{H} 1, \mathrm{H} 2$ and $\mathrm{H} 3$. Among the interactions, model 2 shows a positive interaction effect of family ownership on the relation between independent director interlocks and international investments. Model 3 shows that family ownership moderates the insider director interlock-international investment relation negatively. Thus, hypotheses 4 and 5 are supported. From model 4, we find that family ownership negatively moderates the relation between board meetings and international investments, supporting hypothesis 6 .

Insert table 3 about here

\subsection{Robustness checks}


We perform two sets of additional analysis in our study. Firstly, we have performed analysis using FSTS (export income as a percentage of total sales) as the dependent variable (e.g. Fuad and Gaur, 2018; Ray et al., 2018, Singla et al., 2014), and the results are presented in Table 4. The results between our original analysis (with log of annual foreign investments as the dependent variable) and the new analysis (with FSTS as the dependent variable) differ only in terms of board meeting impact. In the analysis with FSTS as the dependent variable, board meeting frequency does not have a significant impact on the outcome variable. We posit that this difference is due to the nature of two dependent variables; exports and foreign investments are two distinct strategies for internationalization which exhibit different motivations, resource requirements, cost structures, risks, and consequences (Gaur, Kumar and Singh, 2014). Among these, while exporting strategy needs fewer resources and is reversible, foreign investments require greater commitment of resources ( $\mathrm{Lu}$ and Beamish, 2001; McDougall and Oviatt, 2000). Consequently, while board members provide strong resource advantages towards both exports and foreign investments (Gaur, Kumar and Singh, 2014), it requires discussions amongst board members (meeting frequently) to further materialize the commitment of these resources towards internationalization.

Insert table 4 about here

Secondly, our model could also potentially suffer from selection bias. Sample selection bias may occur when values of a study's dependent variable are missing as a result of another process (Greene, 2011; Sartori, 2003). In our case, this could result in selecting a sample of only those firms which have a greater propensity to have more board interlocks and frequent board meetings, resulting in a non-random sample and a biased estimation, if GLS is used. The estimation of this kind of sample, therefore, requires a two-step procedure, where the first stage determines whether or not an observation in an overall population appears in the final representative sample and the step two consists of modelling the relation between the dependent and independent variables of the final sample (Certo et al., 2016; Wooldridge, 2010). Therefore, we apply the Heckman model, a two-step process for data analysis, developed by Heckman (1976). For this purpose, the first step is identifying a selection variable in first stage, that does not appear in the second stage (Sartori, 2003). The first stage, therefore, uses a Probit model and analyse the determinants of interlocked directors and board meetings in firms. Because we have two different variables (interlocks and board meetings), we run two sets of 
analyses. For interlocks, our dependent variables will take the value 1 for board with interlocked directors, and 0 otherwise. For board meetings, our dependent variable will take value 1 if the annual board meetings are greater than 4 (minimum stipulated by the Securities and Exchanges Board of India), 0 otherwise.

Further, we did a survey of literature to identify the selection criteria that would determine a board with interlocks and meetings. Based on our findings, we use the appointing firm's characteristics, along with our other independent variables as determinants of director interlocks and board meetings (Baccouche, Hadriche and Omri, 2014; Ferris, Liao and Tamm, 2018; Fich and Shivdasani, 2007). Accordingly, the additional selection variables include the firm characteristics such as lagged stock return and sales growth, along with the initial independent variables and fixed year and industry effects.

The non-selection hazard (i.e., the inverse Mills ratio) generated by the first-stage selection model was then included in the second-stage regressions to address potential sample selection biases. The second stage analysis is a GLS estimation, which also includes the inverse Mill's ratio of the first stage Probit regression as a dependent variable.

Tables 5 and 6 presents our estimation results. We have presented stage 1 and 2 estimation results separately for both board interlocks and board meeting frequency. The results from the first stage show that firms with higher sales growth, lower stock returns, higher ROA, larger boards, as well as older and larger firms will have higher levels of interlocks and board meeting frequency. In the second stage of analyses, consistent with our hypotheses and initial analyses, we find that insider and independent director interlocks and board meeting frequency are positively associated with internationalization in firms. Also, while independent interlocks have a higher impact on internationalization in family owned firms, insider interlocks and board meetings are less effective when family ownership is higher.

Insert table 5 about here

Insert table 6 about here 


\section{Discussion}

Research on the effectiveness of board characteristics in emerging markets have demonstrated inconclusive results, with studies suggesting that characteristics such as board independence and monitoring could be irrelevant in emerging market firms (Peng et al., 2003; Young et al., 2001; Young et al., 2008). Hence, recent studies from emerging markets stress the resource dependence role of board of directors in these firms, rather than their monitoring role (Singh and Delios, 2017). In emerging market firms, the resources provided by board directors in the form of information, resource access, experience, relationship and operations management, are found to support internationalization activities in firms (Kor and Sundaramurthy 2009; Ortiz-de-Mandojana et al. 2012). Further, studies on firm governance increasingly highlight involvement of board of directors in decision making, through the director interlocks as well as the frequency of board meetings (e.g. Sarkar, Sarkar and Sen, 2008; Shu et al., 2015; Singh and Delios, 2017). Combining these developments, we evaluate the effectiveness of board involvement, in terms of director interlocks and board meeting frequency, on the internationalization decision of Indian family owned firms. We also differentiate between interlocks offered by independent directors and insider directors, based on the premise that these two categories of directors are different in terms of their resource advantages and the network ties that they provide.

Firstly, our results show that both insider and independent director interlocks as well as board meeting frequency are positively related to international investments in firms. Director interlocks also offers advantage to the firm in terms of the directors' experience, the network advantage they offer and their contribution to opportunity recognition in international markets. In our results, we stand with those studies which argue that interlocked directorates can offer several advantages to focal firms in the form resources and access to suppliers and customers (Booth and Deli, 1996; Mizruchi and Stearns, 1994; Pfeffer, 1972), instead of the ones that argue that 'board busyness' could be detrimental to firm performance (Core, Holthausen, and Larcker, 1999; Fich and Shivdasani, 2007; Shivdasani and Yermack, 1999). Our results show that as far as internationalization strategy is concerned, the net benefit of having an interlocked director with network ties is beneficial for Indian firms. In case of independent directors, the linkages provided by these board members offer competitive advantage to firms that help them in their growth and survival (Luo, 2007; Purkayastha, Manolova and Edelman, 2016). 
Secondly, we also show that these independent director interlocks are even more effective in supporting internationalization activities in firms with higher family ownership. As compared to non-family firms, firms with high family ownership are often limited in their human resources, with managerial and leadership roles donned by individuals having relations with the family (Young et al., 2001). In this context, family firms would benefit more from the presence of independent directors with strong external network linkages who can offer them relational capital and assist them in capability building. Because family-owned firms' board often consist primarily from the family, close friends, as well as business associates (Young et al., 2008), the external linkages, networks and resources that independent directors offer can empower them in their strategic pursuits (Sharif, Kyid, and Wei, 2015). Studies also demonstrate that the resources offered by independent directors (such as the interlocks and related linkages) can also strengthen the Socioemotional Wealth (SEW, which is the noneconomic priorities) of family firms (Johannisson and Huse, 2000; Yu et al., 2015), further supporting their strategic decisions such as internationalization. While the role of independent directors in providing relational capital has been demonstrated for emerging market firms, we demonstrate that firms with a higher family ownership can derive greater benefits out of this.

Thirdly, we examined the role of insider director interlocks in internationalization strategies of Indian firms. We find evidence that insider interlocks promote internationalization in our sample of firms. In addition to being familiar with the firm, its capabilities and resource configurations, this shows that insider directors are effective in scanning the external environment through their interlocks and identify internationalization opportunities which are aligned with the capabilities of the firm. At the same time, this effectiveness is lower among family firms, possibly due to the risk averse nature of families towards international investments, which has been demonstrated in emerging market literature (Panicker et al., 2019; Ray et al., 2018). One of the primary reasons for this is that while the ties of insiders help enhance the information on internationalization opportunities, these do not improve the risk bearing capacity of family owners. Also, insider directors, by their very nature, are agents of the owners, and they can use their presence in the board as a mechanism to assert family preferences in decision making (Chrisman, Chua, and Litz, 2004; García-Ramos, Díaz-Díaz, and García-Olalla, 2017). Consequently, because of the reluctance of family firms to internationalize, the interlocks provided by insiders negate the internationalization of family owned firms. Thus, our results show that kinship ties in the form of insider directors do not necessarily enhance the internationalization decisions in family dominated firms' as much as 
formal ties through independent directors, consequently highlighting one of the limiting role of resource dependence emanating from board members in family owned firms.

Finally, contrary to the arguments that frequent board meetings are a sign of poor performance in firms and can result in wastage of resources such as the directors' time and the firms' finances (Jensen, 1993), our results show that meetings could benefit a firm, as an avenue for both the directors to interact, share ideas and reach consensus (Huse, 2000; Tuggle et al., 2010; Zahra, 1990). Moreover, board meetings also enable firms to utilize the board resources effectively, for instance, it has been identified that resource acquisition through board interlocks are most effective when there are frequent board meetings (Chen and Hsu, 2009; Chen, 2012; Gabrielsson and Winlund, 2000). While these meetings are opportunities for directors to come together, share their ideas and promote internationalization activities in firms, their effectiveness is lower in firms with higher ownership by families, thus highlighting another limiting role of resource dependence (especially utilization) through board meetings in family owned firms. Our findings point to two aspects in emerging markets. Family firms could restrict executive management positions to family members, thus limiting the pool of potential qualified and talented labour resources (Varma, 1998; Jackling and Johl, 2009). This could reduce the overall effectiveness of the board. This plausibly signifies the importance of family meetings (role of kinship) in family firms, which might have a greater role than board meetings in deciding firm strategies.

\section{Theoretical Contribution and Managerial Implications}

Our study contributes to the extant literature in the following manner. Firstly, this study highlights the differences in resource roles provided by independent and insider directors separately and identifies the differences in the effectiveness of their network ties in internationalization of family-dominated firms. Secondly, evaluating the differences in board involvement in internationalization in family dominant firms help us understand the nature of ties and relations that shape strategic decision in these firms. Theoretically, we help delineate the limiting resource provision role of the insider directors vis-à-vis independent directors. We argue that the resource provision role of insider director interlocks does not effectively help in internationalization in comparison to independent director interlocks in family dominated firms. In addition, our study also highlights the limiting role of frequency of board meeting in internationalization of family owned firms. Consequently, our study shows the limiting role of 
resource provision and utilization by family owned firms in comparison to non-family owned firms.

Our study also has managerial implications. We recommend that family firms aiming at international diversification develop more connected and networked independent directors to enable internationalization. Further, family firms should device mechanisms to plausibly integrate family meetings with board meetings so that the board is a part of the decisions. Our results also show that board composition and board meetings are significant in firms considering international investments. Constituting the board with directors who hold directorships in other firms in related industries can provide resource advantages to these firms. At the same time, in family firms, family meetings and agendas should be integrated with actual board meetings so that the resource advantages of board members can be fully derived to the benefit of the firm.

There are a few limitations in our study. Firstly, there are questions related to the actual quality of meetings, exchange of ideas in board meetings and the time devoted to routine tasks as opposed to that of substantive issues. It would have been ideal to examine the reason for a particular meeting and the decisions that came out the meetings, however, we faced constraints of data availability in identifying a measurement that can represent this. Also, in this study we are considering overall network ties provided by interlocked directors, but not measuring their individual social ties, which is a direction for future research. Due to data availability issues, we are also focusing on only two measure of internationalization - namely, level of foreign investments and foreign sales to total sales. A more multi-dimensional measure that could more effectively capture the internationalization strategy, could have added to the robustness of our results.

\section{References}

Abraham, S., Marston, C., \& Jones, E. (2015). Disclosure by Indian companies following corporate governance reform. Journal of Applied Accounting Research, 16(1), 114-137.

Adams, R. B., \& Ferreira, D. (2008). Do directors perform for pay?. Journal of Accounting and Economics, 46(1), 154-171.

Aguilera, R. V., Filatotchev, I., Gospel, H., \& Jackson, G. (2008). An organizational approach to comparative corporate governance: Costs, contingencies, and complementarities. Organization science, 19(3), 475-492. 
Anderson, R. C., \& Reeb, D. M. (2004). Board composition: Balancing family influence in S\&P 500 firms. Administrative science quarterly, 49(2), 209-237.

Andersson, S., Gabrielsson, J., \& Wictor, I. (2004). International activities in small firms: examining factors influencing the internationalization and export growth of small firms. Canadian Journal of Administrative Sciences/Revue Canadienne des Sciences de l'Administration, 21(1), 22-34.

Ashwin, A. S., Krishnan, R. T., \& George, R. (2015). Family firms in India: Family involvement, innovation and agency and stewardship behaviors. Asia Pacific Journal of Management, 32(4), 869-900.

Astrachan, J. H., \& Kolenko, T. A. (1994). A neglected factor explaining family business success: Human resource practices. Family business review, 7(3), 251-262.

Aulakh, P. S., Kotabe, M., \& Teegen, H. (2000). Export strategies and performance of firms from emerging economies: Evidence from Brazil, Chile, and Mexico. Academy of management Journal, 43(3), 342-361.

Autio, E., Sapienza, H. J., \& Almeida, J. G. (2000). Effects of age at entry, knowledge intensity, and imitability on international growth. Academy of management journal, 43(5), 909-924.

Baccouche, S., Hadriche, M., \& Omri, A. (2014). Multiple directorships and board meeting frequency: Evidence from France. Applied Financial Economics, 24(14), 983-992.

Bammens, Y., Voordeckers, W., \& Van Gils, A. (2011). Boards of directors in family businesses: A literature review and research agenda. International Journal of Management Reviews, 13(2), 134-152.

Barontini, R., \& Caprio, L. (2006). The effect of family control on firm value and performance: Evidence from continental Europe. European financial management, 12(5), 689-723.

Barroso, C., Villegas, M. M., \& Pérez-Calero, L. (2011). Board influence on a firm's internationalization. Corporate Governance: An International Review, 19(4), 351-367.

Baysinger, B., \& Hoskisson, R. E. (1990). The composition of boards of directors and strategic control: Effects on corporate strategy. Academy of Management review, 15(1), 72-87.

Bazerman, M. H., \& Schoorman, F. D. (1983). A limited rationality model of interlocking directorates. Academy of Management Review, 8(2), 206-217.

Bhaumik, S. K., Driffield, N., \& Pal, S. (2010). Does ownership structure of emerging-market firms affect their outward FDI? The case of the Indian automotive and pharmaceutical sectors. Journal of International Business Studies, 41(3), 437-450.

Boeker, W., \& Goodstein, J. (1991). Organizational performance and adaptation: Effects of environment and performance on changes in board composition. Academy of Management journal, 34(4), 805-826.

Booth, J. R., \& Deli, D. N. (1996). Factors affecting the number of outside directorships held by CEOs. Journal of Financial Economics, 40(1), 81-104. 
Bourdieu, P. (1986). The forms of capital. Handbook of theory and research for the sociology of education. JG Richardson. New York, Greenwood, 241(258), 19.

Boyd, B. (1990). Corporate linkages and organizational environment: A test of the resource dependence model. Strategic management journal, 11(6), 419-430.

Brick, I. E., \& Chidambaran, N. K. (2010). Board meetings, committee structure, and firm value. Journal of corporate finance, 16(4), 533-553.

Brunello, G., Graziano, C., \& Parigi, B. M. (2003). CEO turnover in insider-dominated boards: The Italian case. Journal of Banking \& Finance, 27(6), 1027-1051.

Brunninge, O., \& Nordqvist, M. (2004). Ownership structure, board composition and entrepreneurship: Evidence from family firms and venture-capital-backed firms. International Journal of Entrepreneurial Behavior \& Research, 10(1/2), 85-105.

Cannella Jr, A. A., Jones, C. D., \& Withers, M. C. (2015). Family-versus lone-foundercontrolled public corporations: Social identity theory and boards of directors. Academy of Management Journal, 58(2), 436-459.

Carcello, J. V., Hermanson, D. R., Neal, T. L., \& Riley Jr, R. A. (2002). Board characteristics and audit fees. Contemporary accounting research, 19(3), 365-384.

Carpenter, M. A., \& Westphal, J. D. (2001). The strategic context of external network ties: Examining the impact of director appointments on board involvement in strategic decision making. Academy of Management journal, 44(4), 639-660.

Carter, D. A., Simkins, B. J., \& Simpson, W. G. (2003). Corporate governance, board diversity, and firm value. Financial review, 38(1), 33-53.

Caves, R. E. (1971). International corporations: The industrial economics of foreign investment. Economica, 38(149), 1-27.

Certo, S. T., Busenbark, J. R., Woo, H. S., \& Semadeni, M. (2016). Sample selection bias and Heckman models in strategic management research. Strategic Management Journal, 37(13), 2639-2657.

Chacar, A., \& Vissa, B. (2005). Are emerging economies less efficient? Performance persistence and the impact of business group affiliation. Strategic Management Journal, 26(10), 933-946.

Chakrabarti, R., Megginson, W., \& Yadav, P. K. (2008). Corporate governance in India. Journal of Applied Corporate Finance, 20(1), 59-72.

Chen, H. L., \& Hsu, W. T. (2009). Family ownership, board independence, and R\&D investment. Family business review, 22(4), 347-362.

Chen, P. L., Kor, Y., Mahoney, J. T., \& Tan, D. (2017). Pre-market entry experience and post-market entry learning of the board of directors: Implications for post-entry performance. Strategic Entrepreneurship Journal, 11(4), 441-463.

Chen, H. L. (2012). Board Characteristics and R\&D Investment: Evidence from Taiwan's Electronics Industry. Advances in Management and Applied Economics, 2(4), 161. 
Chen, H. L. (2011). Internationalization in Taiwanese family firms. Global Journal of Business Research, 5(4), 15-23.

Chen, H. L., Hsu, W. T., \& Chang, C. Y. (2016). Independent directors' human and social capital, firm internationalization and performance implications: An integrated agencyresource dependence view. International Business Review, 25(4), 859-871.

Choi, J. J., Park, S. W., \& Yoo, S. S. (2007). The value of outside directors: Evidence from corporate governance reform in Korea. Journal of financial and Quantitative Analysis, 42(4), 941-962.

Chrisman, J. J., Chua, J. H., \& Litz, R. A. (2004). Comparing the agency costs of family and non-family firms: Conceptual issues and exploratory evidence. Entrepreneurship Theory and practice, 28(4), 335-354.

Coles, J. L., Daniel, N. D., \& Naveen, L. (2008). Boards: Does one size fit all?. Journal of financial economics, 87(2), 329-356.

Conger, J. A., Finegold, D., \& Lawler, E. E. (1998). Appraising boardroom performance. Harvard business review, 76, 136-164.

Core, J. E., Holthausen, R. W., \& Larcker, D. F. (1999). Corporate governance, chief executive officer compensation, and firm performance. Journal of financial economics, 51(3), 371-406.

Dalton, D. R., Daily, C. M., Ellstrand, A. E., \& Johnson, J. L. (1998). Meta-analytic reviews of board composition, leadership structure, and financial performance. Strategic management journal, 19(3), 269-290.

Dalziel, T., Gentry, R. J., \& Bowerman, M. (2011). An integrated agency-resource dependence view of the influence of directors' human and relational capital on firms' R\&D spending. Journal of Management Studies, 48(6), 1217-1242.

Datta, D. K., Musteen, M., \& Herrmann, P. (2009). Board characteristics, managerial incentives, and the choice between foreign acquisitions and international joint ventures. Journal of Management, 35(4), 928-953.

Dearborn, D. C., \& Simon, H. A. (1958). Selective perception: A note on the departmental identifications of executives. Sociometry, 21(2), 140-144.

Demb, A., \& Neubauer, F. F. (1992). The corporate board: Confronting the paradoxes. Long range planning, 25(3), 9-20.

Dharwadkar, B., George, G., \& Brandes, P. (2000). Privatization in emerging economies: An agency theory perspective. Academy of management review, 25(3), 650-669.

Donaldson, L., \& Davis, J. H. (1991). Stewardship theory or agency theory: CEO governance and shareholder returns. Australian Journal of management, 16(1), 49-64.

Donaldson, L. (1995). American anti-management theories of organization: A critique of paradigm proliferation (Vol. 25). Cambridge University Press.

Dunning, J. H. (1998). Location and the multinational enterprise: a neglected factor?. Journal of international business studies, 29(1), 45-66. 
Elango, B., \& Pattnaik, C. (2007). Building capabilities for international operations through networks: a study of Indian firms. Journal of international business studies, 38(4), 541-555.

Faccio, M., \& Lasfer, M. A. (2000). Do occupational pension funds monitor companies in which they hold large stakes?. Journal of Corporate Finance, 6(1), 71-110.

Fahlenbrach, R., Low, A., \& Stulz, R. M. (2010). Why do firms appoint CEOs as outside directors?. Journal of Financial Economics, 97(1), 12-32.

Ferris, S. P., Jagannathan, M., \& Pritchard, A. C. (2003). Too busy to mind the business? Monitoring by directors with multiple board appointments. The Journal of finance, 58(3), 1087-1111.

Ferris, S. P., Liao, M. Y. S., \& Tamm, C. (2018). The compensation of busy directors: An international analysis. Research in International Business and Finance, 46, 294-312.

Fich, E. M., \& Shivdasani, A. (2007). Financial fraud, director reputation, and shareholder wealth. Journal of Financial Economics, 86(2), 306-336.

Fich, E. M. (2005). Are some outside directors better than others? Evidence from director appointments by Fortune 1000 firms. The Journal of Business, 78(5), 1943-1972.

Filatotchev, I. (2006). Effects of executive characteristics and venture capital involvement on board composition and share ownership in IPO firms. British Journal of Management, 17(1), $75-92$.

Fuad, M., \& Gaur, A. S. (2019). Merger waves, entry-timing, and cross-border acquisition completion: A frictional lens perspective. Journal of World Business, 54(2), 107-118.

Gabrielsson, J., \& Winlund, H. (2000). Boards of directors in small and medium-sized industrial firms: examining the effects of the board's working style on board task performance. Entrepreneurship \& Regional Development, 12(4), 311-330.

García-Ramos, R., Díaz-Díaz, B., \& García-Olalla, M. (2017). Independent directors, large shareholders and firm performance: the generational stage of family businesses and the socioemotional wealth approach. Review of Managerial Science, 11(1), 119-156.

Garg, S., \& Eisenhardt, K. M. (2017). Unpacking the CEO-board relationship: How strategy making happens in entrepreneurial firms. Academy of Management Journal, 60(5), 1828-1858.

Gaur, A. S., \& Kumar, V. (2009). International diversification, business group affiliation and firm performance: Empirical evidence from India. British Journal of Management, 20(2), 172186.

Gaur, A. S., Kumar, V., \& Singh, D. (2014). Institutions, resources, and internationalization of emerging economy firms. Journal of World Business, 49(1), 12-20.

Gersick, K. E., Gersick, K. E., Davis, J. A., Hampton, M. M., \& Lansberg, I. (1997). Generation to generation: Life cycles of the family business. Harvard Business Press.

Goodstein, J., Gautam, K., \& Boeker, W. (1994). The effects of board size and diversity on strategic change. Strategic management journal, 15(3), 241-250. 
Granovetter, M. (1995). Coase revisited: Business groups in the modern economy. Industrial and corporate change, 4(1), 93-130.

Graves, C., \& Thomas, J. (2008). Determinants of the internationalization pathways of family firms: An examination of family influence. Family Business Review, 21(2), 151-167.

Greene, W. (2011). Limited dependent models: Censoring, truncation, and sample selection. Econometric Analysis, 7.

Grinyer, P., \& McKiernan, P. (1990). Generating major change in stagnating companies. Strategic Management Journal, 131-146.

Gulati, R. (1998). Alliances and networks. Strategic management journal, 19(4), 293-317.

Habbershon, T. G., \& Astrachan, J. H. (1997). Research note: Perceptions are reality: How family meetings lead to collective action. Family Business Review, 10(1), 37-52.

Hassel, A., Höpner, M., Kurdelbusch, A., Rehder, B., \& Zugehör, R. (2003). Two dimensions of the internationalization of firms. Journal of Management Studies, 40(3), 705-723.

Haynes, K. T., \& Hillman, A. (2010). The effect of board capital and CEO power on strategic change. Strategic Management Journal, 31(11), 1145-1163.

Heckman, J. J. (1976). The common structure of statistical models of truncation, sample selection and limited dependent variables and a simple estimator for such models. In Annals of economic and social measurement, volume 5, number 4 (pp. 475-492). NBER.

Hillman, A. J., \& Dalziel, T. (2003). Boards of directors and firm performance: Integrating agency and resource dependence perspectives. Academy of Management review, 28(3), 383396.

Hillman, A. J., Cannella, A. A., \& Paetzold, R. L. (2000). The resource dependence role of corporate directors: Strategic adaptation of board composition in response to environmental change. Journal of Management studies, 37(2), 235-256.

Hillman, A. J., Withers, M. C., \& Collins, B. J. (2009). Resource dependence theory: A review. Journal of management, 35(6), 1404-1427.

Hitt, M. A., Bierman, L., Uhlenbruck, K., \& Shimizu, K. (2006). The importance of resources in the internationalization of professional service firms: The good, the bad, and the ugly. Academy of management journal, 49(6), 1137-1157.

Huse, M. (1995). Stakeholder thinking and the board of directors in owner/manager firms. Understanding stakeholder thinking, 197-214.

Huse, M. (2000). Boards of directors in SMEs: A review and research agenda. Entrepreneurship \& Regional Development, 12(4), 271-290.

Hymer, S. H. (1976). International operations of national firms. MIT press.

Jackling, B., \& Johl, S. (2009). Board structure and firm performance: Evidence from India's top companies. Corporate Governance: An International Review, 17(4), 492-509. 
Jain, S. C. (Ed.). (2006). Emerging economies and the transformation of international business: Brazil, Russia, India and China (BRICs). Edward Elgar Publishing

Jaiswall, M., \& Banerjee, A. (2012). Exploring the relationship between Earnings Management and Corporate Governance characteristics in the Indian context. IIM Calcutta WPS No, 704.

Jensen, M. C. (1993). The modern industrial revolution, exit, and the failure of internal control systems. the Journal of Finance, 48(3), 831-880

Johannisson, B., \& Huse, M. (2000). Recruiting outside board members in the small family business: An ideological challenge. Entrepreneurship \& Regional Development, 12(4), 353 378.

Johl, S. K., Kaur, S., \& Cooper, B. J. (2015). Board characteristics and firm performance: Evidence from Malaysian public listed firms. Journal of Economics, Business and Management, 3(2), 239-243.

Johnson, J. L., Daily, C. M., \& Ellstrand, A. E. (1996). Boards of directors: A review and research agenda. Journal of management, 22(3), 409-438.

Johnson, R. A., Hoskisson, R. E., \& Hitt, M. A. (1993). Board of director involvement in restructuring: The effects of board versus managerial controls and characteristics. Strategic Management Journal, 14(S1), 33-50.

Judge Jr, W. Q., \& Zeithaml, C. P. (1992). Institutional and strategic choice perspectives on board involvement in the strategic decision process. Academy of management Journal, 35(4), 766-794.

Kali, R. (1999). Endogenous business networks. Journal of Law, Economics, and Organization, 15(3), 615-636.

Kang, J. K., \& Shivdasani, A. (1995). Firm performance, corporate governance, and top executive turnover in Japan. Journal of financial economics, 38(1), 29-58.

Khanna, T., \& Rivkin, J. W. (2001). Estimating the performance effects of business groups in emerging markets. Strategic management journal, 22(1), 45-74.

Khanna, T., \& Palepu, K. (2000a). Emerging market business groups, foreign intermediaries, and corporate governance. In Concentrated corporate ownership (pp. 265-294). University of Chicago Press.

Khanna, T., \& Palepu, K. (2000b). Is group affiliation profitable in emerging markets? An analysis of diversified Indian business groups. The journal of finance, 55(2), 867-891.

Khanna, T., Kogan, J., \& Palepu, K. (2006). Globalization and similarities in corporate governance: A cross-country analysis. Review of Economics and Statistics, 88(1), 69-90.

Kono, C., Palmer, D., Friedland, R., \& Zafonte, M. (1998). Lost in space: The geography of corporate interlocking directorates. American journal of sociology, 103(4), 863-911.

Kor, Y. Y., \& Sundaramurthy, C. (2009). Experience-based human capital and social capital of outside directors. Journal of management, 35(4), 981-1006. 
Korac-Kakabadse, N., Kakabadse, A. K., \& Kouzmin, A. (2001). Board governance and company performance: any correlations?. Corporate Governance: The international journal of business in society, 1(1), 24-30.

Kostova, T., \& Zaheer, S. (1999). Organizational legitimacy under conditions of complexity: The case of the multinational enterprise. Academy of Management review, 24(1), 64-81.

Langevoort, D. C. (2001). Seeking sunlight in Santa Fe's shadow: The SEC's pursuit of managerial accountability. Wash. ULQ, 79, 449.

Lester, R. H., \& Cannella Jr, A. A. (2006). Interorganizational familiness: How family firms use interlocking directorates to build community-level social capital. Entrepreneurship Theory and Practice, 30(6), 755-775.

Lipton, M., \& Lorsch, J. W. (1992). A modest proposal for improved corporate governance. The business lawyer, 59-77.

Lorsch, J., \& Young, J. (1990). Pawns or potentates: The reality of America's corporate boards. Academy of Management Perspectives, 4(4), 85-87.

Lu, J. W., \& Beamish, P. W. (2001). The internationalization and performance of SMEs. Strategic management journal, 22(6-7), 565-586.

Luan, C. J., \& Tang, M. J. (2007). Where is independent director efficacy?. Corporate Governance: An International Review, 15(4), 636-643.

Luo, Y. (2007). Global dimensions of corporate governance. Wiley-Blackwell.

Martini, S. B., Corvino, A., \& Rigolini, A. (2012). Board Diversity and Investments in Innovation: Empirical Evidence from Italian Context. Corporate Ownership \& Control, 10(1), 9-25.

Masulis, R. W., Wang, C., \& Xie, F. (2012). Globalizing the boardroom-The effects of foreign directors on corporate governance and firm performance. Journal of Accounting and Economics, 53(3), 527-554.

McDougall, P. P., \& Oviatt, B. M. (2000). International entrepreneurship: the intersection of two research paths. Academy of management Journal, 43(5), 902-906.

Min, B. S., \& Chizema, A. (2018). Board meeting attendance by outside directors. Journal of Business Ethics, 147(4), 901-917.

Mitter, C., Duller, C., Feldbauer-Durstmüller, B., \& Kraus, S. (2014). Internationalization of family firms: the effect of ownership and governance. Review of Managerial Science, 8(1), 128.

Mizruchi, M. S., \& Stearns, L. B. (1994). A longitudinal study of borrowing by large American corporations. Administrative Science Quarterly, 39(1).

Mizruchi, M. S., \& Stearns, L. B. (1988). A longitudinal study of the formation of interlocking directorates. Administrative Science Quarterly, 194-210.

Mizruchi, M. S. (1996). What do interlocks do? An analysis, critique, and assessment of research on interlocking directorates. Annual review of sociology, 22(1), 271-298. 
Mustakallio, M., Autio, E., \& Zahra, S. A. (2002). Relational and contractual governance in family firms: Effects on strategic decision making. Family business review, 15(3), 205-222.

Neubauer, F., \& Lank, A. G. (1998). Stages of Evolution of Family Enterprises. In The Family Business (pp. 26-55). Palgrave Macmillan, London.

Ntim, C. G., \& Osei, K. A. (2011). The impact of corporate board meetings on corporate performance in South Africa. African Review of Economics and Finance, 2(2), 83-103.

Ortiz-de-Mandojana, N., Aragón-Correa, J. A., Delgado-Ceballos, J., \& Ferrón-Vílchez, V. (2012). The effect of director interlocks on firms' adoption of proactive environmental strategies. Corporate Governance: An International Review, 20(2), 164-178.

Palmer, D. (2002). Interlocking directorates and intercorporate coordination. Social Networks: Critical Concepts in Sociology, 3, 261.

Palmer, D. A., Jennings, P. D., \& Zhou, X. (1993). Late adoption of the multidivisional form by large US corporations: Institutional, political, and economic accounts. Administrative science quarterly, 100-131.

Panicker, V. S., Mitra, S., \& Upadhyayula, R. S. (2019). Institutional investors and international investments in emerging economy firms: A behavioral risk perspective. Journal of World Business, 54(4), 322-334.

Pearce, J. A., \& Zahra, S. A. (1992). Board composition from a strategic contingency perspective. Journal of management studies, 29(4), 411-438.

Peng, M. W., Buck, T., \& Filatotchev, I. (2003). Do outside directors and new managers help improve firm performance? An exploratory study in Russian privatization. Journal of World Business, 38(4), 348-360.

Pennings, J. M. (1980). Interlocking directorates: Origins and consequences of connections among organizations' Board of Directors. Jossey-Bass.

Perry, T., \& Peyer, U. (2005). Board seat accumulation by executives: A shareholder's perspective. The Journal of Finance, 60(4), 2083-2123.

Pettigrew, A. M. (1992). The character and significance of strategy process research. Strategic management journal, 13(S2), 5-16.

Pfeffer, J., \& Salancik, G. R. (2003). The external control of organizations: A resource dependence perspective. Stanford University Press.

Pfeffer, J. (1972). Size and composition of corporate boards of directors: The organization and its environment. Administrative science quarterly, 218-228.

Pfeffer, J. (1987). A resource dependence perspective on intercorporate relations. Intercorporate relations: The structural analysis of business, 1(1), 25-55.

Pombo, C., \& Gutiérrez, L. H. (2011). Outside directors, board interlocks and firm performance: Empirical evidence from Colombian business groups. Journal of Economics and Business, 63(4), 251-277. 
Putnam, R. (1993). The prosperous community: Social capital and public life. The american prospect, 13(Spring), Vol. 4. Available online: http://www. prospect. org/print/vol/13 (accessed 7 April 2003).

Ramón-Llorens, M.C., García-Meca, E. and Duréndez, A., 2017. Influence of CEO characteristics in family firms internationalization. International Business Review, 26(4), pp.786-799.

Ray, S., Mondal, A., \& Ramachandran, K. (2018). How does family involvement affect a firm's internationalization? An investigation of Indian family firms. Global Strategy Journal, 8(1), 73-105.

Rosenstein, S., \& Wyatt, J. G. (1994). Shareholder wealth effects when an officer of one corporation joins the board of directors of another. Managerial and Decision Economics, 15(4), 317-327.

Ruigrok, W., Peck, S. I., \& Keller, H. (2006). Board characteristics and involvement in strategic decision making: Evidence from Swiss companies. Journal of management Studies, 43(5), 1201-1226.

Saeed, A., Yousaf, A. and Alharbi, J., 2017. Family and state ownership, internationalization and corporate board-gender diversity: Evidence from China and India. Cross Cultural \& Strategic Management, 24(2), pp.251-270.

Sarkar, J., Sarkar, S. and Sen, K., 2008. Board of directors and opportunistic earnings management: Evidence from India. Journal of Accounting, Auditing \& Finance, 23(4), pp.517551.

Sartori, A. E. (2003). An estimator for some binary-outcome selection models without exclusion restrictions. Political Analysis, 11(2), 111-138.

Sciascia, S., Mazzola, P., Astrachan, J.H. and Pieper, T.M., 2013. Family involvement in the board of directors: Effects on sales internationalization. Journal of Small Business Management, 51(1), pp.83-99.

Sharif, S. P., Kyid, Y. K., \& Wei, K. K. (2015). The Acquisition of Valuable Resources by Family-Controlled Companies in Malaysia Through Political Connections of Their Independent Directors. The Journal of Developing Areas, 49(5), 309-319.

Sherman, H. D., Kashlak, R. J., \& Joshi, M. P. (1998). The effect of the board and executive committee characteristics on the degree of internationalization. Journal of International Management, 4(4), 311-335.

Shivdasani, A., \& Yermack, D. (1999). CEO involvement in the selection of new board members: An empirical analysis. The journal of finance, 54(5), 1829-1853.

Shu, P.G., Yeh, Y.H., Chiu, S.B. and Yang, Y.W., 2015. Board external connectedness and earnings management. Asia Pacific Management Review, 20(4), pp.265-274.

Silva, F., \& Majluf, N. (2008). Does family ownership shape performance outcomes?. Journal of Business Research, 61(6), 609-614. 
Silva, F., Majluf, N. and Paredes, R., 2006. Ownership structure and performance: Empirical evidence from Chilean firms. Corporate Ownership and Control, 3(4), pp.173-181.

Singh, D., \& Delios, A. (2017). Corporate governance, board networks and growth in domestic and international markets: Evidence from India. Journal of World Business, 52(5), 615-627.

Singh, D. A., \& Gaur, A. S. (2013). Governance structure, innovation and internationalization: Evidence from India. Journal of International Management, 19(3), 300-309.

Singla, C., Veliyath, R., \& George, R. (2014). Family firms and internationalization-governance relationships: Evidence of secondary agency issues. Strategic Management Journal, 35(4), 606-616

Sundaramurthy, C., \& Lewis, M. (2003). Control and collaboration: Paradoxes of governance. Academy of management review, 28(3), 397-415.

Tihanyi, L., Johnson, R. A., Hoskisson, R. E., \& Hitt, M. A. (2003). Institutional ownership differences and international diversification: The effects of boards of directors and technological opportunity. Academy of Management Journal, 46(2), 195-211.

Tuggle, C. S., Sirmon, D. G., Reutzel, C. R., \& Bierman, L. (2010). Commanding board of director attention: investigating how organizational performance and CEO duality affect board members' attention to monitoring. Strategic Management Journal, 31(9), 946-968.

Useem, M. (1982). Classwide rationality in the politics of managers and directors of large corporations in the United States and Great Britain. Administrative Science Quarterly, 199226.

Vafeas, N. (1999). Board meeting frequency and firm performance. Journal of financial economics, 53(1), 113-142.

Varma, J. R. (1998). Indian financial sector reforms: A corporate perspective. Vikalpa, 23(1), 27-38.

Walsh, J. P. (1995). Managerial and organizational cognition: Notes from a trip down memory lane. Organization science, 6(3), 280-321.

Ward, J. L., \& Handy, J. L. (1988). A survey of board practices. Family Business Review, 1(3), 289-308.

Wennberg, K., Wiklund, J., Hellerstedt, K., \& Nordqvist, M. (2011). Implications of intra-family and external ownership transfer of family firms: short-term and long-term performance differences. Strategic Entrepreneurship Journal, 5(4), 352-372.

Wernerfelt, B. (1984). A resource-based view of the firm. Strategic management journal, 5(2), 171-180.

Westhead, P., Wright, M., \& Ucbasaran, D. (2001). The internationalization of new and small firms: A resource-based view. Journal of business venturing, 16(4), 333-358. 
Westphal, J. D. (1999). Collaboration in the boardroom: Behavioral and performance consequences of CEO-board social ties. Academy of management Journal, 42(1), 7-24.

Westphal, J. D., \& Zajac, E. J. (1997). Defections from the inner circle: Social exchange, reciprocity, and the diffusion of board independence in US corporations. Administrative science quarterly, 161-183.

Wincent, J., Anokhin, S., \& Örtqvist, D. (2010). Does network board capital matter? A study of innovative performance in strategic SME networks. Journal of Business Research, 63(3), $265-275$.

Wooldridge, J. M. (2010). Econometric analysis of cross section and panel data. MIT press.

Xie, B., Davidson III, W. N., \& DaDalt, P. J. (2003). Earnings management and corporate governance: the role of the board and the audit committee. Journal of corporate finance, 9(3), 295-316.

Young, M. N., Ahlstrom, D., Bruton, G. D., \& Chan, E. S. (2001). The resource dependence, service and control functions of boards of directors in Hong Kong and Taiwanese firms. Asia Pacific Journal of Management, 18(2), 223-244.

Young, M. N., Peng, M. W., Ahlstrom, D., Bruton, G. D., \& Jiang, Y. (2008). Corporate governance in emerging economies: A review of the principal-principal perspective. Journal of management studies, 45(1), 196-220.

Yu, A., Ding, H. B., \& Chung, H. M. (2015). Corporate social responsibility performance in family and non-family firms: The perspective of socio-emotional wealth. Asian Business \& Management, 14(5), 383-412.

Zahra, S. A. (1990). Increasing the board's involvement in strategy. Long Range Planning, 23(6), 109-117.

Zona, F., Gomez-Mejia, L. R., \& Withers, M. C. (2018). Board interlocks and firm performance: Toward a combined agency-resource dependence perspective. Journal of management, 44(2), 589-61. 
Table 1: Variable definitions and computation

\begin{tabular}{|c|c|c|c|}
\hline Variable name & Definition/Computation & References & Type of variable \\
\hline Internationalization & Logarithm of annual foreign investments of the firm & $\begin{array}{l}\text { Panicker et al, 2019; Singh and Gaur, } \\
2013\end{array}$ & Dependent variable \\
\hline FSTS & Annual foreign sales to total sales & $\begin{array}{l}\text { Fuad and Sinha, 2018; Ray, Mondal and } \\
\text { Ramachandran, 2018; Singla et al., } 2014\end{array}$ & Dependent variable \\
\hline Independent interlocks & $\begin{array}{l}\text { Total number of interlocks provided by all independent } \\
\text { directors/total number of independent directors }\end{array}$ & $\begin{array}{l}\text { Filatotchev, 2006; Ortiz-de-Mandojana et } \\
\text { al., } 2012\end{array}$ & Explanatory variable \\
\hline Insider interlocks & $\begin{array}{l}\text { Total number of interlocks provided by all insider } \\
\text { directors/total number of insider directors }\end{array}$ & $\begin{array}{l}\text { Filatotchev, 2006; Ortiz-de-Mandojana et } \\
\text { al., } 2012\end{array}$ & Explanatory variable \\
\hline Board meetings & Total number of board meetings by the firm every year & Jackling and Johl, 2009; Vafaes, 1999 & Explanatory variable \\
\hline Board size & Number of directors on the board & $\begin{array}{l}\text { Singh and Gaur, 2013; Singh and Delios, } \\
2017\end{array}$ & Control variable \\
\hline Board independence & $\begin{array}{l}\text { Number of independent directors/ total number of directors } \\
\text { on the board }\end{array}$ & $\begin{array}{l}\text { Singh and Gaur, 2013; Singh and Delios, } \\
2017\end{array}$ & Control variable \\
\hline CEO Duality & $\begin{array}{l}\text { Dummy variable, value }=1 \text { if } \mathrm{CEO} \text { and Chairperson are the } \\
\text { same person, } 0 \text { otherwise }\end{array}$ & Jackling and Johl, 2009 & Control variable \\
\hline Family ownership & Percentage of shareholding with the founding family & Ashwin et al., 2015; Ray et al., 2018 & Control variable \\
\hline Business group affiliation & $\begin{array}{l}\text { Dummy variable, value }=1 \text { if the firm is affiliated to a } \\
\text { business group, } 0 \text { otherwise }\end{array}$ & Chittoor et al., 2015; Panicker et al., 2019 & Control variable \\
\hline Institutional ownership & Percentage of shareholding with the institutional shareholders & Singh and Gaur, 2013; & Control variable \\
\hline RnD intensity & RnD expenditure/Total sales & $\begin{array}{l}\text { Singh and Delios, 2017; Panicker et al., } \\
2019\end{array}$ & Control variable \\
\hline Age & Age of the firm & Chittoor et al., 2015; Panicker et al., 2019 & Control variable \\
\hline Firm size & Logarithm of total assets of the firm & \multirow{3}{*}{$\begin{array}{l}\text { Tihanyi et al., 2003; Gaur and Kumar, } \\
\text { 2009; Autio, Sapienza and Almeida, } 2000\end{array}$} & Control variable \\
\hline Profitability & Logarithm of return on assets & & Control variable \\
\hline DE ratio & Debt to equity ratio & & Control variable \\
\hline
\end{tabular}


Table 2: Summary statistics and correlation matrix

4

\begin{tabular}{|c|c|c|c|c|c|c|c|c|c|c|c|c|c|c|c|c|c|}
\hline 5 & +8 & Mean & $\begin{array}{l}\text { Std } \\
\text { Dev }\end{array}$ & 1 & 2 & 3 & 4 & 5 & 6 & 7 & 8 & 9 & 10 & 11 & 12 & 13 & 14 \\
\hline 7 & 1. Foreign investments & 51.08 & 277.07 & 1 & & & & & & & & & & & & & \\
\hline $\begin{array}{c}8 \\
9 \\
\end{array}$ & 2.FSTS & 8.76 & 177.24 & -0.02 & 1 & & & & & & & & & & & & \\
\hline & 3.Independent interlocks & 2.14 & 2.42 & $0.08 *$ & $-0.02 *$ & 1 & & & & & & & & & & & \\
\hline & 4.Insider interlocks & 1.82 & 2.51 & $0.06^{*}$ & $-0.02 *$ & $0.43^{*}$ & 1 & & & & & & & & & & \\
\hline 12 & 5.Board meetings & 4.57 & 1.59 & 0.011 & $-0.02 *$ & $0.05^{*}$ & $0.05^{*}$ & 1 & & & & & & & & & \\
\hline 14 & 6.Board size & 8.08 & 3.32 & $0.14^{*}$ & $-0.04^{*}$ & $0.28 *$ & $0.23 *$ & $0.14^{*}$ & 1 & & & & & & & & \\
\hline & 7.Board independence & 0.48 & 0.13 & 0.007 & $0.03 *$ & $-0.03 *$ & $0.04 *$ & $-0.02 *$ & $-0.21 *$ & 1 & & & & & & & \\
\hline & 8.Family ownership & 46.57 & 20.14 & $-0.07 *$ & $-0.02 *$ & $0.06^{*}$ & $0.06^{*}$ & $-0.02 *$ & $0.07 *$ & $-0.11 *$ & 1 & & & & & & \\
\hline 17 & 9.Institutional investors & 7.39 & 11.01 & $0.19 *$ & -0.012 & $0.25 *$ & $0.21 *$ & $0.09 *$ & $0.31 *$ & $0.03 *$ & $-0.19 *$ & 1 & & & & & \\
\hline 19 & 10.Total assets & 182.4 & 1412.1 & $0.45 *$ & -0.01 & $0.11 *$ & $0.08 *$ & $0.03 *$ & $0.2 *$ & $-0.01 *$ & $-0.02 *$ & $0.23 *$ & 1 & & & & \\
\hline 20 & 11.RnD intensity & 0.01 & 0.04 & $0.06^{*}$ & $0.04 *$ & $-0.04 *$ & -0.004 & 0.0042 & $-0.05^{*}$ & 0.008 & $-0.08^{*}$ & $0.04 *$ & -0.01 & 1 & & & \\
\hline 21 & $12 . \mathrm{ROA}$ & -2.78 & 133.00 & 0.006 & -0.006 & $0.02 *$ & 0.01 & $0.03 *$ & $0.04 *$ & $-0.03 *$ & $0.024 *$ & -0.002 & 0.007 & $-0.03 *$ & 1 & & \\
\hline 22 & 13.DE ratio & 2.14 & 28.12 & 0.012 & -0.002 & -0.011 & 0.001 & 0.008 & 0.0103 & -0.003 & 0.0036 & -0.008 & -0.001 & -0.018 & $-0.04 *$ & 1 & \\
\hline & 14.Age & 30.02 & 17.11 & 0.006 & $-0.02 *$ & $0.18 *$ & $0.11 *$ & $-0.02 *$ & $0.2 *$ & $-0.01 *$ & $0.11^{*}$ & $0.11 *$ & $0.04 *$ & $-0.13 *$ & -0.006 & -0.003 & 1 \\
\hline
\end{tabular}

* Correlation is significant at the 0.01 level (2-tailed). 
Table 3: Results of GLS regression on the effect of board characteristics on internationalization measured as foreign investments

\begin{tabular}{|c|c|c|c|c|c|c|c|c|c|c|c|c|c|c|c|c|}
\hline 5 & 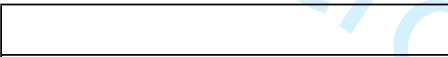 & & Model 1 & & & Model 2 & & & Model 3 & & & Model 4 & & & Model 5 & \\
\hline & & $\beta$-value & Std. dev & p-value & $\beta$-value & Std. dev & p-value & $\beta$-value & Std. dev & p-value & $\beta$-value & Std. dev & p-value & $\beta$-value & Std. dev & p-value \\
\hline 8 & Independent interlocks & 0.023 & 0.018 & 0.018 & 0.023 & 0.018 & 0.016 & 0.021 & 0.048 & 0.006 & 0.024 & 0.018 & 0.017 & 0.034 & 0.049 & 0.019 \\
\hline 9 & Insider interlocks & 0.002 & 0.013 & 0.001 & 0.002 & 0.012 & 0.007 & 0.002 & 0.013 & 0.014 & -0.023 & 0.032 & 0.016 & -0.024 & 0.031 & 0.030 \\
\hline & Board meetings & 0.004 & 0.013 & 0.009 & 0.114 & 0.043 & 0.008 & -0.004 & 0.013 & 0.007 & -0.004 & 0.013 & 0.007 & 0.113 & 0.044 & 0.010 \\
\hline 11 & Board size & 0.023 & 0.016 & 0.158 & 0.023 & 0.016 & 0.151 & 0.023 & 0.016 & 0.159 & 0.023 & 0.016 & 0.152 & 0.024 & 0.016 & 0.145 \\
\hline & Board independence & -0.082 & 0.352 & 0.816 & -0.080 & 0.353 & 0.820 & -0.083 & 0.356 & 0.815 & -0.081 & 0.351 & 0.817 & -0.074 & 0.357 & 0.837 \\
\hline & 4 CEO-Chairperson & 0.134 & 0.123 & 0.277 & 0.105 & 0.123 & 0.394 & 0.134 & 0.124 & 0.277 & 0.153 & 0.126 & 0.227 & 0.124 & 0.126 & 0.325 \\
\hline & Family ownership & -0.003 & 0.003 & 0.202 & 0.009 & 0.005 & 0.091 & -0.004 & 0.004 & 0.375 & -0.005 & 0.003 & 0.116 & 0.008 & 0.006 & 0.189 \\
\hline & Business group affiliation & -0.179 & 0.244 & 0.461 & -0.187 & 0.242 & 0.440 & -0.180 & 0.244 & 0.461 & -0.181 & 0.244 & 0.459 & -0.188 & 0.242 & 0.437 \\
\hline 11 & Institutional investments & 0.015 & 0.006 & 0.017 & 0.015 & 0.006 & 0.015 & 0.015 & 0.006 & 0.017 & 0.015 & 0.006 & 0.017 & 0.015 & 0.006 & 0.015 \\
\hline & Firm size & 0.700 & 0.072 & 0.000 & 0.704 & 0.071 & 0.000 & 0.700 & 0.072 & 0.000 & 0.704 & 0.072 & 0.000 & 0.708 & 0.072 & 0.000 \\
\hline & RnD intensity & 0.987 & 0.307 & 0.022 & 0.048 & 0.321 & 0.021 & 0.985 & 0.308 & 0.022 & 0.977 & 0.300 & 0.022 & 0.041 & 0.315 & 0.021 \\
\hline & Profitability & -0.009 & 0.028 & 0.740 & -0.007 & 0.029 & 0.817 & -0.010 & 0.029 & 0.738 & -0.010 & 0.028 & 0.727 & -0.007 & 0.029 & 0.818 \\
\hline & DE ratio & -0.065 & 0.040 & 0.107 & -0.062 & 0.041 & 0.129 & -0.065 & 0.040 & 0.107 & -0.066 & 0.041 & 0.104 & -0.062 & 0.041 & 0.127 \\
\hline 2 & Age & -0.005 & 0.005 & 0.309 & -0.005 & 0.005 & 0.316 & -0.005 & 0.005 & 0.311 & -0.005 & 0.005 & 0.305 & -0.005 & 0.005 & 0.310 \\
\hline & $\begin{array}{l}\text { Independent director } \\
\text { interlock * Family } \\
\text { ownership }\end{array}$ & & & & 0.001 & 0.001 & 0.016 & & & & & & & 0.002 & 0.001 & 0.005 \\
\hline & $\begin{array}{l}\text { Insider director interlock * } \\
\text { Family ownership }\end{array}$ & & & & & & & -0.001 & 0.001 & 0.039 & & & & -0.000 & 0.001 & 0.019 \\
\hline & $\begin{array}{l}\text { Board meeting*Family } \\
\text { ownership }\end{array}$ & & & & & & & & & & -0.002 & 0.001 & 0.004 & -0.001 & 0.001 & 0.042 \\
\hline 32 & R-squared & 0.61 & & & 0.62 & & & 0.62 & & & 0.62 & & & 0.62 & & \\
\hline
\end{tabular}

$\mathrm{N}=3133$. All explanatory variables have been lagged by one year. Industry and year have been controlled for, but not reported. The reported standard errors are computed through clustering by firm technique. 
Table 4: Results of GLS regression on the effect of board characteristics on internationalization measured as foreign sales to total sales

\begin{tabular}{|c|c|c|c|c|c|c|c|c|c|c|c|c|c|c|c|}
\hline 8 & \multicolumn{3}{|c|}{ Model 1} & \multicolumn{3}{|c|}{ Model 2} & \multicolumn{3}{|c|}{ Model 3} & \multicolumn{3}{|c|}{ Model 4} & \multicolumn{3}{|c|}{ Model 5} \\
\hline 8 & $\beta$-value & Std. dev & p-value & $\beta$-value & Std. dev & p-value & $\beta$-value & Std. dev & $\mathrm{p}$-value & $\beta$-value & Std. dev & $\mathrm{p}$-value & $\beta$-value & Std. dev & $\mathrm{p}$-value \\
\hline 8 Independent interlocks & 0.021 & 0.013 & 0.009 & 0.021 & 0.013 & 0.009 & 0.016 & 0.027 & 0.005 & 0.021 & 0.013 & 0.009 & 0.019 & 0.030 & 0.009 \\
\hline 9Insider interlocks & 0.012 & 0.014 & 0.013 & 0.012 & 0.014 & 0.014 & 0.012 & 0.014 & 0.016 & 0.016 & 0.017 & 0.036 & 0.004 & 0.020 & 0.037 \\
\hline 1Board meetings & -0.013 & 0.011 & 0.041 & -0.023 & 0.041 & 0.070 & -0.013 & 0.011 & 0.047 & -0.013 & 0.011 & 0.042 & -0.024 & 0.040 & 0.054 \\
\hline 1 Board size & -0.007 & 0.011 & 0.547 & -0.007 & 0.011 & 0.548 & -0.007 & 0.011 & 0.540 & -0.007 & 0.011 & 0.548 & -0.007 & 0.011 & 0.551 \\
\hline 13 Board independence & 0.264 & 0.302 & 0.382 & 0.266 & 0.302 & 0.379 & 0.274 & 0.304 & 0.367 & 0.266 & 0.301 & 0.377 & 0.273 & 0.302 & 0.366 \\
\hline 14EO-Chairperson & 0.159 & 0.237 & 0.504 & 0.161 & 0.238 & 0.500 & 0.157 & 0.238 & 0.508 & 0.158 & 0.238 & 0.505 & 0.159 & 0.238 & 0.503 \\
\hline 15amily ownership & -0.002 & 0.002 & 0.465 & -0.003 & 0.004 & 0.566 & 0.001 & 0.003 & 0.720 & -0.001 & 0.003 & 0.643 & 0.000 & 0.005 & 0.937 \\
\hline 1థusiness group affiliation & -0.429 & 0.163 & 0.009 & -0.429 & 0.163 & 0.009 & -0.428 & 0.163 & 0.009 & -0.429 & 0.163 & 0.009 & -0.429 & 0.163 & 0.009 \\
\hline Institutional investments & 0.004 & 0.002 & 0.083 & 0.004 & 0.002 & 0.084 & 0.004 & 0.002 & 0.093 & 0.004 & 0.002 & 0.084 & 0.004 & 0.002 & 0.095 \\
\hline $\begin{array}{l}18 \\
19 \\
19 \text { irm size }\end{array}$ & -0.303 & 0.059 & 0.000 & -0.303 & 0.059 & 0.000 & -0.304 & 0.059 & 0.000 & -0.303 & 0.059 & 0.000 & -0.304 & 0.059 & 0.000 \\
\hline 2QRnD intensity & 0.601 & 0.902 & 0.752 & 0.595 & 0.900 & 0.754 & 0.590 & 0.907 & 0.757 & 0.603 & 0.902 & 0.751 & 0.578 & 0.906 & 0.762 \\
\hline 2Profitability & -0.043 & 0.028 & 0.124 & -0.043 & 0.028 & 0.125 & -0.041 & 0.028 & 0.139 & -0.043 & 0.028 & 0.123 & -0.041 & 0.028 & 0.139 \\
\hline 2ZE ratio & -0.002 & 0.008 & 0.764 & -0.003 & 0.008 & 0.753 & -0.002 & 0.008 & 0.794 & -0.002 & 0.008 & 0.766 & -0.002 & 0.008 & 0.783 \\
\hline 23. & -0.003 & 0.003 & 0.239 & -0.003 & 0.003 & 0.233 & -0.003 & 0.003 & 0.235 & -0.003 & 0.003 & 0.241 & -0.003 & 0.003 & 0.228 \\
\hline $\begin{array}{l}25 \text { Independent director } \\
26 \text { hnterlock } * \text { Family } \\
29 \text { wnership }\end{array}$ & & & & 0.001 & 0.001 & 0.015 & & & 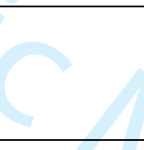 & & & & 0.002 & 0.001 & 0.049 \\
\hline $\begin{array}{l}\text { 28nsider director interlock } \\
29 \text { Family ownership }\end{array}$ & & & & & & & -0.002 & 0.001 & 0.024 & & & & -0.001 & 0.001 & 0.009 \\
\hline $\begin{array}{l}\text { 36 Board meeting*Family } \\
\text { 31 } \\
\text { ownership }\end{array}$ & & & & & & & & & & -0.002 & 0.001 & 0.017 & -0.003 & 0.002 & 0.039 \\
\hline 32 -squared & 0.26 & & & 0.27 & & & 0.27 & & & 0.27 & & & 0.27 & & \\
\hline
\end{tabular}

$\mathrm{N}=7539$. All explanatory variables have been lagged by one year. Industry and year have been controlled for, but not reported. The reported standard errors are computed through clustering by firm technique. 
Table 5: Results of Heckman 2 stage regression on the effect of board interlocks on internationalization measured as foreign investments

\begin{tabular}{|l|r|r|r|}
\hline \multicolumn{4}{|c|}{ Heckman stage 1, DV: Presence of board interlocks } \\
\hline & \multicolumn{1}{|c|}{$\beta$-value } & Std. dev & \multicolumn{1}{c|}{ p-value } \\
\hline Stock return & -0.147 & 0.059 & 0.019 \\
\hline Sales growth & 0.002 & 0.001 & 0.012 \\
\hline Profitability & 0.021 & 0.127 & 0.017 \\
\hline Firm size & 0.169 & 0.147 & 0.001 \\
\hline Firm Age & 0.001 & 0.009 & 0.051 \\
\hline Board size & 0.088 & 0.055 & 0.011 \\
\hline Board independence & 0.366 & 1.037 & 0.724 \\
\hline CEO-Chairperson & 0.001 & 0.024 & 0.825 \\
\hline Family ownership & -0.017 & 0.010 & 0.074 \\
\hline Business group affiliation & 1.163 & 0.364 & 0.001 \\
\hline Institutional investments & -0.001 & 0.017 & 0.939 \\
\hline RnD intensity & -6.574 & 2.516 & 0.009 \\
\hline DE ratio & -0.031 & 0.068 & 0.644 \\
\hline N & \multicolumn{3}{|c}{} \\
\hline
\end{tabular}

\begin{tabular}{|c|c|c|c|}
\hline \multicolumn{4}{|c|}{ Heckman stage 2, DV: Annual foreign investments } \\
\hline & $\beta$-value & Std. dev & $\mathrm{p}$-value \\
\hline Independent interlocks & 0.131 & 0.067 & 0.018 \\
\hline Insider interlocks & 0.047 & 0.052 & 0.035 \\
\hline Board meetings & 0.036 & 0.040 & 0.041 \\
\hline Board size & 0.053 & 0.022 & 0.013 \\
\hline Board independence & 0.155 & 0.583 & 0.791 \\
\hline CEO-Chairperson & -0.101 & 0.321 & 0.752 \\
\hline Family ownership & -0.023 & 0.005 & 0.000 \\
\hline Business group affiliation & 0.125 & 0.116 & 0.280 \\
\hline Institutional investments & 0.015 & 0.005 & 0.007 \\
\hline Firm size & 0.964 & 0.067 & 0.000 \\
\hline RnD intensity & 0.837 & 0.607 & 0.000 \\
\hline Profitability & 0.074 & 0.063 & 0.242 \\
\hline DE ratio & -0.098 & 0.042 & 0.019 \\
\hline Age & -0.010 & 0.003 & 0.000 \\
\hline $\begin{array}{l}\text { Independent director interlock } \\
* \text { Family ownership }\end{array}$ & 0.004 & 0.001 & 0.007 \\
\hline $\begin{array}{l}\text { Insider director interlock } * \\
\text { Family ownership }\end{array}$ & -0.001 & 0.001 & 0.025 \\
\hline Lambda & 1.254 & 0.213 & 0.000 \\
\hline R-squared & 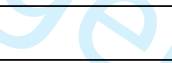 & 0.46 & \\
\hline $\mathrm{N}$ & & 3133 & \\
\hline
\end{tabular}


Table 6: Results of Heckman 2 stage regression on the effect of board meeting frequency on internationalization measured as foreign investments

\begin{tabular}{|l|r|r|r|}
\hline \multicolumn{4}{|c|}{ Heckman stage 1, DV: Presence of board meetings } \\
\hline & $\beta$-value & Std. dev & p-value \\
\hline Stock return & -0.072 & 0.029 & 0.011 \\
\hline Sales growth & 0.003 & 0.000 & 0.019 \\
\hline Profitability & 0.077 & 0.049 & 0.015 \\
\hline Firm size & 0.053 & 0.047 & 0.026 \\
\hline Firm Age & 0.002 & 0.002 & 0.047 \\
\hline Board size & 0.020 & 0.019 & 0.029 \\
\hline Board independence & -0.153 & 0.448 & 0.732 \\
\hline CEO-Chairperson & 0.268 & 0.440 & 0.542 \\
\hline Family ownership & 0.005 & 0.003 & 0.063 \\
\hline Business group affiliation & 0.030 & 0.101 & 0.768 \\
\hline Institutional investments & 0.015 & 0.006 & 0.014 \\
\hline RnD intensity & -1.482 & 1.157 & 0.200 \\
\hline DE ratio & -0.018 & 0.024 & 0.468 \\
\hline N & & 8751 & \\
\hline
\end{tabular}

\begin{tabular}{|l|r|r|r|}
\hline \multicolumn{4}{|c|}{ Heckman stage 2, DV: Annual foreign investments } \\
\hline & $\beta$-value & \multicolumn{1}{c|}{ Std. dev } & p-value \\
\hline Independent interlocks & 0.022 & 0.027 & 0.021 \\
\hline Insider interlocks & 0.054 & 0.022 & 0.015 \\
\hline Board meetings & 0.410 & 0.158 & 0.009 \\
\hline Board size & 0.031 & 0.025 & 0.223 \\
\hline Board independence & 0.313 & 0.721 & 0.664 \\
\hline CEO-Chairperson & -0.245 & 0.381 & 0.520 \\
\hline Family ownership & 0.030 & 0.016 & 0.064 \\
\hline Business group affiliation & 0.079 & 0.133 & 0.550 \\
\hline Institutional investments & 0.017 & 0.006 & 0.010 \\
\hline Firm size & 1.077 & 0.100 & 0.000 \\
\hline RnD intensity & 0.847 & 0.494 & 0.000 \\
\hline Profitability & 0.245 & 0.090 & 0.007 \\
\hline DE ratio & -0.139 & 0.043 & 0.001 \\
\hline Age & -0.012 & 0.003 & 0.000 \\
\hline $\begin{array}{l}\text { Board meetings * Family } \\
\text { ownership }\end{array}$ & -0.008 & 0.003 & 0.012 \\
\hline Lambda & 1.869 & 0.372 & 0.000 \\
\hline R-squared & & 0.46 & \\
\hline N & & 3133 & \\
\hline
\end{tabular}

Industry and year have been controlled for, but not reported 